\title{
Earnings quality in ex-post failed firms
}

\section{Juan Manuel García Lara, Beatriz García Osma and Evi Neophytou*}

\begin{abstract}
This paper analyses earnings quality in ex-post failed firms. Using a lage sample of UK bankrupt firms, we find that failed firms manage earnings upwards in the four years prior to failure. This manipulation is achieved in two ways: (1) through accounting (accruals) manipulation; and (2) by implementing real operating actions that deviate from normal practice. We show that these two types of manipulation lead to reduced earnings reliability We use conditional conservatism as a proxy for reliability , as prior literature links conditional accounting conservatism to better governance and positive economic outcomes. Our results show that conditional conservatism decreases substantially in the years prior to failure. Finally we show that accruals manipulation is more pronounced in ex-post bankrupt firms with low ex-ante probability of failure, and that ex-post bankrupt firms with high ex-ante failure probability, having likely exhausted the opportunities for accrual manipulation, manipulate real operations more aggressively.

Keywords: firm failure, accruals management, real earnings management, conditional conservatism. earnings quality, bankruptcy
\end{abstract}

\section{Introduction}

We analyse earnings quality for a lar ge sample of UK failed firms in the four years before failure (from year $t-4$ to year $t$, where $t$ is the year of firm failure). While there is extensive research analysing the quality of accounting numbers in financially troubled firms, empirical evidence on the earnings behaviour of ex-post bankrupt (failed) firms in the years leading up to bankruptcy is scarce. Prior research has focused exclusively on accounting manipulation either in the year immediately prior to failure (Smith et al., 2001) or aggregating information from the years before failure (Rosner, 2003). These studies do not consider how manipulation evolves as failure approaches, and report only descriptive evidence of real activities manipulation. In addition, they fail to provide evidence on the consequences that managerial manipulation has over the reliability or usefulness of earnings. ${ }^{1}$

We ar gue that in the presence of deteriorating

*Juan Manuel García Lara is at Universidad Carlos III de Madrid, Beatriz García Osma is at Universidad Autónoma de Madrid and Evi Neophytou is at Athens University of Economics and Business.

The authors are grateful to Pauline Weetman (the editor), Peter F. Pope, Steve Young and two anonymous reviewers for their helpful comments and suggestions. The paper has benefited from presentations at the 2006 EAA annual conference and at the 1st International Conference in Accounting and Finance at the University of Macedonia, Thessaloniki. We acknowledge financial contribution from the European Commission INTACCT Research Training Network (MRTNCT-2006-035850), and the Spanish Ministry of Science and Innovation (ECO2008-0638/ECON and SEJ200767582/ECON and SEJ2005-08644/ECO).

Correspondence should be sent to Beatriz García Osma, Universidad Autónoma de Madrid, Departamento Contabilidad, Avda. Fco Tomas y Valiente 5, Madrid 28049 (Spain). Tel.+34914972970. E-mail: beatriz.garcia@uam.es.

This paper was accepted for publication in December 2008. firm performance: (1) managers of ex-post failed firms manipulate both accruals and real activities to conceal poor performance in the years preceding failure; however, (2) as failure approaches, and when the opportunities for further accrual manipulation are exhausted, it is anticipated that prior manipulation will reverse into lar ge negative accruals. Hence, prior studies in this area that aggregate data from the final years prior to bankruptcy or analyse only the year before failure, potentially provide confounding evidence on earnings quality patterns in ex-post failed firms. Generally, we expect that managers prefer the manipulation of accruals over the manipulation of real activities, as the latter is more costly Consequently, (3) managers are likely to resort to the manipulation of real activities only when there is limited scope left for accrual manipulation. Finally, we argue that (4) the manipulation of both accruals and real activities has severe consequences on the reliability of earnings for decision-making. We expect that managerial manipulation reduces the reliability of accounting numbers, leading to reduced conditional conservatism. Therefore, we explore and provide new evidence on three important aspects that have not been analysed in detail by prior work, namely managerial use of accounting and real activities manipulation to hide poor performance, how manipulation evolves as failure looms closer and the opportunities for successfully postponing bankruptcy diminish,

\footnotetext{
${ }^{1}$ To be consistent with international literature, we use the term 'bankruptcy' to refer to firm failure. However, in the UK this term is only appropriate for individuals. According to the UK Insolvency Act 1986, the correct term to use for companies is insolvency (see www .insolvency.gov.uk). We use 'failure', 'insolvency' and 'bankruptcy' interchangeably throughout the paper.
} 
and the consequences of this manipulation on the reliability of earnings.

Furthering our understanding of these three issues is crucial for: (1) the adequate development of new accounting standards and corporate governance regulations aimed at tackling opportunistic managerial behaviour in financially troubled firms; as well as (2) the improvement of bankruptcy prediction models, by explicitly taking into account managerial attempts to hide poor performance. It is commonly accepted that investors can predict bankruptcy fairly accurately using prediction models. However, these models are based to a great extent on accounting data that can be manipulated by management (Ohlson, 1980). We show that managers make both accounting and operating decisions that af fect the reliability of accounting numbers, and how these decisions accumulate and reverse in the year prior to bankruptcy . This evidence is potentially important in designing bankruptcy prediction models that may be able to account for the observations reported in this paper. Finally, we provide limited evidence (3) that managers manipulate real decisions to postpone bankruptcy. This evidence raises awareness of sub-optimal decision making that may be particularly relevant for debt holders and claimants. Suboptimal operating, financing or investment decision-making may deplete the firm of some of its assets or, at the very least, reduce their liquidation value. The evidence on real actions is of interest to those directly involved in the liquidation process of the company, in terms of timing the decision on when to initiate a winding-up petition, or to best estimate the liquidation value of the firm prior to bankruptcy.

Using a lar ge sample of continuing and failed UK firms from 1995 to 2004, we find that ex-post failed firms engage in both accounting manipulation and real activities manipulation in the four years prior to failure. This is consistent with the evidence in Beaver (1966) that the properties of accounting numbers between failing and continuing firms differ in the five years prior to the failure event. As bankruptcy approaches, the manipulation unravels and we observe large negative accruals in the year just before failure. We analyse the existence of accounting and real activities manipulation using discretionary accruals models (Jones, 1991; Dechow et al. 1995; Kasznik, 1999) and the abnormal cash flow model proposed by Dechow et al. (1998) as implemented by Roychowdhury (2006). Our results provide evidence consistent with the existence of managerial preferences and trade-offs in selecting earnings management instruments as suggested - but untested - by prior research (e.g. Peasnell et al., 2000). We show that firms with a higher probability of bankruptcy, likely having exhausted their opportunities for suc- cessful accounting manipulation, engage in the manipulation of real activities. Our sample of failed firms provides a good setting for a test of real earnings management, because even if real manipulation implies higher costs, bankruptcy is certainly more costly. Finally, our results are consistent with managers successfully concealing poor performance through accounting manipulation, as we find that accruals manipulation is more pronounced in ex-post failed firms with low exante failure probability.

In what we think is a significant contribution of the paper, we formally assess the impact of these two types of manipulation on the reliability or usefulness of earnings. To do so, we analyse if ex-post failed firms report significantly less conditionally conservative earnings than continuing firms. Following Basu (1997), we identify conditional conservatism with an asymmetric recognition of economic gains and losses into earnings, and we measure it using the methodology proposed by Ball and Shivakumar (2005). ${ }_{2}$ Prior research shows that conditional conservatism is a desirable property of earnings as it is a key corporate governance provision that provides important economic benefits such as reducing agency problems driven by information asymmetries (Beekes et al., 2004; Ahmed and Duellman, 2007; García Lara et al., 2007, 2009; LaFond and Watts, 2008), and that it varies substantially across firms in a predictable way (e.g. Ball et al., 2000; Qiang, 2007), especially when there are dif ferences in accrual-based earnings management (García Lara et al., 2005). Our results show that ex-post bankrupt firms report less conditionally conservative earnings in the years prior to failure than continuing firms. This reduced conditional conservatism, as suggested by prior research, increases agency problems and the probability of stakeholder expropriation.

The paper makes several contributions to the existing literature. Specifically, we add to the stream of research on the quality of earnings in failed firms in several ways. First, we analyse two different aspects of earnings management: accounting manipulation and real activity manipulation, showing that managers resort to both. We also provide evidence on the timing of the manipulation,

\footnotetext{
${ }^{2}$ We use the term conditional conservatism following Beaver and R yan (2005). Other studies use 'earnings conservatism', 'income-statement conservatism', 'ex-post conservatism' or 'news-driven' conservatism to refer to the same phenomenon.

${ }^{3}$ Prior research assumes the manipulation is the same from five years prior to bankruptcy to the year just before bankruptcy (Rosner, 2003), or analyses only the manipulation in the year just before failure (Smith et al., 2001). By aggregating data over the years prior to failure, an analysis would similarly classify a firm that steadily increases earnings quality from low to high with a firm that does the reverse; as on average across the five years they would both look similar when they are indeed very different.
} 
as we show it starts four years prior to failure, and that accrual manipulation unravels in the year just before failure. ${ }^{3}$ Second, we show ex-post failed firms with a low ex-ante failure probability engage in more pronounced accruals manipulation. We interpret this evidence as firms being successful in hiding poor performance through accruals manipulation. On the other hand, firms with a high exante failure probability, having likely exhausted their opportunities for accrual manipulation, manipulate real activities more aggressively . Third, we conduct conditional conservatism tests to analyse whether the manipulation (both accounting and real activities manipulation) leads to more aggressive accounting. We find that ex-post failed firms report less conditionally conservative earnings and, as suggested by prior research in conditional conservatism, this implies increased agency problems. Finally, prior research has focused on the US (Rosner, 2003), or in periods of recession (Smith et al., 2001). We use a UK sample over the period 1995-2004. The UK insolvency code allows for a wider definition of bankruptcy, with different implications, than in the US (Franks et al., 1996; Bradbury, 2007).

The remainder of the paper is structured as follows. Section 2 reviews the existing literature in this area and presents the research questions. Section 3 details the sample selection procedure and describes the methodology. Section 4 discusses the empirical results and Section 5 concludes.

\section{Background and research questions}

\subsection{Firm failure in the UK}

The UK Insolvency Act 1986 and its subsequent amendments govern the legal failure routes, rules and regulations for insolvent British companies. The Act provides several legal courses of action for companies in financial distress, the most common and popular ones being administration, administrative receivership and liquidation.

An administration order is a court order placing a company that is, or is likely to become, insolvent under the control of an administrator following a petition by the company, its directors or a creditor (Part II, Insolvency Act 1986, s. 8-27). The purpose of the order is to preserve the company' $\mathrm{s}$ business and assets to allow a reor ganisation, or ensure the most advantageous realisation of its assets whilst protecting it from action by its creditors.

An administrative receivership arises as a result of a company defaulting on secured borrowing (Part III, Insolvency Act 1986, s. 28-72). The borrowing is usually from a bank. Under receivership, a receiver is appointed by the creditor to run the company with the objective of recovering the outstanding bank finance, through any means (Chapter I, Part III). From a company point of view, the company is rarely saved in its existing form, its assets are often subject to a meltdown and often jobs and economic activity is lost.

Finally, the liquidation or winding up of companies is the procedure whereby the assets of a company are gathered in and realised, the liabilities are met, and surplus, if any exists, is distributed to members (Part IV , Insolvency Act 1986, s. 73-219). Liquidation can be either compulsory or voluntary. In compulsory liquidation, a winding-up petition is initiated, usually by a creditor due to an outstanding debt that the company has not paid (Chapter VI, Part IV , Insolvency Act 1986). Voluntary liquidation is the placing of the company into liquidation by resolution of its members. There are two types of voluntary liquidation: creditors' voluntary liquidation and members' voluntary liquidation. In the former case, the directors of the company, who assess that the company is, or will be, insolvent, approach an insolvency practitioner to wind up the company. In such cases, the creditors have the right to reject (by value of vote) the choice of the liquidator chosen by the company directors (Chapter IV , Part IV, Insolvency Act 1986). On the other hand, a members' voluntary liquidation does not involve insolvency and comes about merely because the company shareholders wish to have the value of their holding realised (Chapter III, Part IV, Insolvency Act 1986).

\subsection{Prior evidence on earnings management in financially distressed firms}

Prior research on earnings management by troubled companies commonly focuses on firms that are showing signs of financial distress. A popular proxy for distress is debt covenant violation.

Positive accounting theory predicts that firms approaching covenant violations will make incomeincreasing accounting choices to loosen their debt constraints (W atts and Zimmerman, 1986). Sweeney (1994) and DeFond and Jiambalvo (1994) find evidence consistent with this hypothesis. Nonetheless, results are not always consistent; in fact, several studies find firms in distress reporting large negative accruals (DeAngelo et al., 1994; Peltier -Rivest, 1999; Saleh and Ahmed, 2005), and argue that managers prefer to reflect the firm's financial troubles to signal their willingness to deal with them (DeAngelo et al., 1994), or to obtain concessions from labour unions and subsidies from government. In all likelihood, a number of these financially troubled firms will approach or enter into technical default. However, covenant violations are not always associated with increased distress risk. To account for this, several studies employ alternative definitions of distress such as dividend declines and series of consecutive losses (DeAngelo et al., 1994; Peltier -Rivest, 1999), or receiving going-concern audit opinions (Butler et al., 2004). These studies find that distressed firms 
have large negative, performance-related accruals, but do not attribute this finding to earnings management practices. Instead, they ar gue that firms with high risk of failure engage in liquidity enhancing transactions in an attempt to survive.

The proxies used by prior research are likely to overstate the actual cases of severely troubled firms. Clearly, a more objective definition of financial distress is legal (involuntary) failure. Few studies, however, make use of bankruptcy data, probably due to the inherent dif ficulty in finding adequate data for firms that do not exist anymore. Also, bankruptcy presents a rather narrow definition of failure, with only a very small percentage of listed firms going bankrupt. However, the stakeholders of a failed company suf fer more severe losses than those of firms exhibiting weak performance. Hence, the detection of aggressive accounting practices in the years that precede bankruptcy becomes critical.

Only the prior work of Smith et al. (2001), Rosner (2003) and Charitou et al. (2007a, 2007b) directly examines the properties of earnings in actually failed firms. For an Australian sample, Smith et al. find that ex-post bankrupt firms do not engage in accounting changes to inflate earnings in the year just before failure (year $t-1$ ). They find that distressed firms that do not end up being bankrupt change their accounting policies to increase earnings. However, they do not directly examine whether ex-post bankrupt firms changed their accounting policies in the years before $t$-1, while managers still believe in the recovery of the firm. ${ }^{4}$ Also, they do not separately analyse accrual accounting behaviour in bankrupt firms with a low ex-ante probability of bankruptcy . Because their benchmark for failure is set on a specific date (12 months after filing the 1988 accounts), they cannot follow up on the behaviour of their distressed company sample. In contrast, our procedure allows us to follow up on firms that show little outward signs of distress but end up bankrupt. Since we do not know if the distressed firms in the Smith et al. study ended up bankrupt, their results on accounting changes in a period of economic downturn are dif ficult to interpret. Additionally, these changes in policies have to be reported in the financial statements, and thus, as earnings management instruments, they lack the element of concealment.

More closely related to our study, Rosner (2003) investigates accrual manipulation on a sample of 293 failed US companies and finds that firms ma-

\footnotetext{
${ }^{4}$ Their sample covers only 1988 . As they recognise, their evidence might not be generalisable due to the stock market crash of 1987 and the subsequent financial crisis (likely leading to increased monitoring). We cover a longer and more stable time period (1998-2004), in a stable macroeconomic environment (the UK).
}

nipulate earnings upwards in pre-bankruptcy nongoing-concern years. However, in her tests she pools all years together and assumes that the manipulation of earnings in ex-post bankrupt firms is the same during the five years prior to failure. Our results indicate that this is not the case. In addition, she shows that in the year preceding failure, firms receiving going-concern opinions exhibit incomedecreasing behaviour. She attributes this to the over statement reversals that auditors demand when they eventually detect a going-concern problem.

Finally, the work of Charitou et al. (2007a, 2007b), which closely relates to that of Rosner (2003), uses a sample of US firms that filed for Chapter 11 to analyse earnings management practices in distressed firms. However, their focus is on analysing the role played by auditors and other monitoring bodies in constraining earnings manipulation in the year just before bankruptcy and on the links between earnings manipulation in the year prior to filing for bankruptcy and the likelihood of survival thereafter.

\subsection{Research questions}

\subsubsection{Accounting manipulation}

Firms approaching bankruptcy probably engage in income-increasing earnings management practices (decreasing cost of goods sold, releasing bad debt accruals, etc.) in an attempt to ride out what is probably deemed by management as a temporary bad period. Managerial optimism most likely prevails, leading managers to maintain the belief that firm performance will improve in the following periods and thus, to keep manipulating earnings upwards even when they know that their actions will accumulate and reverse in the future (Graham et al., 2005). However, there are limits to managerial optimistic biases. The balance sheet accumulates previous decisions, placing constraints to the number of consecutive years when over -optimism can be exerted without committing GAAP violations (Barton and Simko, 2002). Precisely because firms end up failed, there is an assurance that deteriorating financial health was not a temporary concern. It is expected that: (1) the scope for accrual management will decrease as bankruptcy approaches, as managers exhaust their opportunities for successful manipulation; and also that (2) the actions undertaken in the years leading up to bankruptcy will accumulate in the final year, cascading into large negative accruals when previous manipulation reverses and deteriorating performance cannot be hidden any longer. Thus, we test the following hypotheses (in alternative form):

H1A: Failed firms manage earnings in the years before failure;

H1B: In the year prior to bankruptcy , as managers exhaust their opportunities for 
successful accrual manipulation, previously manipulated accruals reverse, leading to an accumulation of negative accruals just before failure.

\subsubsection{Real earnings management}

Following Roychowdhury (2006), we define real earnings manipulation as 'management actions that deviate from normal business practices, undertaken with the primary objective of meeting certain earnings thresholds' (p. 336). Earnings incentives give rise to sub-optimal operating, investment and financing decision making, when managers resort to real actions to meet their income tar gets. The seminal work of Schipper (1989: 92) puts forward as an example of real earnings management the timing of investment or financing decisions to alter reported earnings. Subsequent research demonstrates that managers time the sale of long-lived assets and investments (Bartov, 1993), delay and abandon research and development projects, give more lenient credit terms or reduce necessary expenses such as those on advertising and asset maintenance to meet their earnings tar gets (Bushee, 1998; Graham et al., 2005, Roychowdhury , 2006; Cohen et al., 2008; García Osma and Young, 2009). ${ }^{5}$ Thus, whilst real earnings management is not an entirely accounting phenomenon (in that it is not directly achieved through accounting), it is driven by the desire to keep up accounting appearances. A survey by Graham et al. (2005) of 401 financial executives indicates a preference for real actions over purely accounting decisions to manipulate earnings. Similar UK survey studies present comparable views (Demirag, 1995; Grinyer et al., 1998).

In the case of failing firms, real earnings manipulation is aimed at increasing current earnings to conceal poor performance. However, real earnings manipulation is expected to reduce future cash flows, and, consequently, firm value. As pointed out by Peasnell et al. (2000: 420-421) the use of sub-optimal operating strategies is more costly than the reversals from accruals, and, consequently a more aggressive form of earnings management and thus, a last resource for management. However, even if real earnings manipulation is costly, bankruptcy is certainly even more so. In failed firms, the years prior to bankruptcy

\footnotetext{
${ }^{5}$ For example, if a covenant in a debt contract demands a minimum ROA of $2 \%$, and true ROA is $1.9 \%$, management may bridge the gap between both numbers by increasing net income artificially via accrual management that requires either accounting (e.g. reducing the provision for bad debts for the year) or real manipulation (e.g. relaxing credit terms to increase revenues), or both. This effect may also be achieved by selling assets, which would reduce the denominator (less assets) and increase the nominator (more cash or accruals), or by reducing discretionary expenses.
}

are probably characterised by more aggressive accounting practices, and in all likelihood, also by the undertaking of real actions to manage earnings and perceptions, particularly in those firms that have exhausted their possibilities for successful accrual manipulation. Therefore, we extend our analysis to study abnormal cash flow activity.

\section{H2: Failed firms engage in real earnings manipulation in the years before failure. Real earnings management will be more pronounced if the firm' s financial condi- tion is weak and the possibilities for accru- al manipulation have been exhausted.}

\subsubsection{Effects of accounting and real earnings manipulation on the usefulness of earnings}

Prior research on earnings management in healthy firms shows that often discretionary accruals are value-relevant and are used by managers as a signalling device (Guay et al., 1996; Subramanyam, 1996). Healy and Palepu (1993) argue that income-increasing strategies have signalling value if they are used to communicate increases in future earnings to investors. In those cases, discretionary accruals can increase the usefulness of accounting numbers. However , as our sample comprises only ex-post bankrupt firms, we expect that income-increasing discretionary accruals in the years preceding failure will be due to opportunistic managerial behaviour.

Early work on failed firms only studies the magnitude of the proxies for income-increasing strategies to ascertain whether they respond to signalling vs. opportunistic reporting. We go one step beyond the descriptive evidence on the quantity of policy changes and discretionary accruals in Smith et al. (2001) and Rosner (2003) and explicitly analyse the consequences of managerial manipulation by studying if the reliability of accounting numbers in failed firms is hindered by their income increasing strategies. To do so, we study the conditional conservatism of earnings in failed vs. continuing firms.

We choose conditional conservatism as a benchmark to assess whether the usefulness of earnings declines in ex-post bankrupt firms as a result of both accounting and real activities manipulation for several reasons: (1) conditional conservatism is a summary measure of managerial reporting choices; (2) extant evidence demonstrates that better governed firms report more conditionally conservative earnings as a response to investors demands, who consider it as a desirable property of earnings (Beekes et al., 2004; Ahmed and Duellman, 2007; García Lara et al., 2007, 2009); and (3) recent research shows that conditionally conservative accounting leads to positive economic outcomes such as an ameliora- 
tion of the problems derived from information asymmetries (LaFond and Watts, 2008), or improvements in contracting ef ficiency (Ball et al., 2008).

Following Basu (1997), we define conditional conservatism as a timelier recognition of economic losses than economic gains in earnings. ${ }^{6}$ For example, increases in the value of assets are not reflected in the profit and loss account, while decreases are reflected through impairments. At the root of this asymmetric treatment for the recognition of economic gains and losses in earnings is the principle of conservatism or prudence that is embedded into most regulatory accounting frameworks (F ASB, 1980; IASC, 1989; ASB, 1999). This asymmetry in recognition requirements results in earnings that reflect bad news faster than good news (Basu, 1997). Timely loss recognition is expected to constrain management's opportunistic payments to themselves and to other parties, and is considered a desirable property of accounting earnings (Ball and Shivakumar, 2005) that mitigates moral hazard problems.

We hypothesise that in the years prior to failure, failed firms will show less conditionally conservative earnings than financially sound firms, because failed firms are likely to engage in less conservative accounting practices in those years to conceal their true economic performance (Ohlson, 1980), and in an attempt to postpone bankruptcy . As a consequence of this more aggressive (less conservative) accounting, managers relax the requirements for economic gains recognition, anticipating their recognition, while at the same time they attempt to delay the recognition of losses. Failing firms tend to have increasing inventories and increasing debtors (increase in accruals with reduced certainty of becoming cash flows). Although the ASB Statement of Principles (1999) does not prescribe conservative accounting, it states (ch. 3) that 'a degree of caution' has to be 'applied in

\footnotetext{
${ }^{6}$ Beaver and R yan (2005) identify two separate types of conservatism: conditional and unconditional. It is important to distinguish between them. They define unconditional conservatism as a persistent understatement of assets due to the use of accounting conventions at the inception of assets and liabilities, such as the non-recognition of internally generated intangible assets or the use of historical cost. Ball and Shivakumar (2005) argue that unconditional conservatism introduces a bias of unknown magnitude in the financial statements that does not contribute to contracting efficiency. Thus, in our study, we analyse only the conditional form.

${ }^{7}$ Prior research on failed firms like Rosner (2003) compares failed firms earnings quality estimates to those of matched non-bankrupt control samples, considering only firms with sound financial performance and avoiding cases that exhibit net losses. Excluding distressed firms biases the procedure in favour of finding the hypothesised result of dif ferences between failed and continuing firms, especially if a number of continuing firms face financial problems, as happens in the UK (Neophytou and Mar Molinero, 2004).
}

exercising the necessary judgements'. Managers are thus expected to exercise caution and respond to this situation by increasing bad debt provisions and by impairing inventories. However, as pointed out by Ohlson (1980), when failure approaches, managers are expected to relax their conservative policies to try to delay it. Similar to Rosner (2003), we argue that if this is indeed the case, managers are likely to resort to aggressive accrual management in the years prior to failure. This aggressive accrual management could be achieved by, for example, not increasing bad debt provisions and not impairing inventories adequately.

Conditional conservatism is also expected to be affected by real earnings management. In an attempt to increase earnings, managers may aggressively relax credit terms, by selling on credit to customers with high ex-ante credit risk. This would lead to increases in the percentage of expected bad debts. Similar to the prior case, under the framework of the ASB, managers are expected to respond by increasing bad debt provisions.

Failure to do so in an attempt to increase earnings would lead to aggressive instead of conservative accounting. The joint ef fect of both accruals and real activities manipulation in ex-post failed firms is expected to reduce the conservatism of accounting numbers in these firms. Consequently , our third and final hypothesis is as follows:

H3: Ex-post failed firms present less conditionally conservative earnings numbers than continuing firms in the years preceding bankruptcy.

\section{Research method and sample selection procedure}

We compare earnings quality between failed and continuing firms. Earnings quality is a broad concept with multiple dimensions (e.g. Al-Attar et al., 2008; Barker and Imam, 2008). We focus on earnings management and its influence on accounting reliability, as measured by conditional conservatism. Measures of earnings management and timely loss recognition are calculated for the full sample, to avoid biasing in favour of our hypothesis that earnings quality is lower in failed firms. This section provides details of the calculation of these measures and describes the sample selection procedure.

\subsection{Measurement of accounting accruals manipulation}

Ex-post failed firms may attempt to conceal deteriorating firm performance by using income-increasing accounting accruals. Extant research calculates abnormal accruals using the Jones (1991) model in cross-section, to improve the estimation of the parameters, as suggested by DeFond 
and Jiambalvo (1994). The Jones model uses the unexplained part of a regression of total accruals on the change in revenue and gross property, plant and equipment as a proxy for abnormal accruals. We use the working capital version of the model because current research indicates that management has more discretion over current accruals, and that manipulation of long-term accruals such as depreciation is unlikely due to their high visibility and low flexibility (Becker et al., 1998; Young, 1999).

Aside from the working capital version of the Jones (1991) model, we also use the modified Jones model. The Jones (1991) model assumes that revenues are not discretionary . That is, the model disregards the possibility that managers also engage in real activities manipulation, by accruing revenues before the cash is received and when it is still questionable that the revenues have been earned. By assuming all revenues are nondiscretionary, the Jones model removes part of the manipulation from the abnormal accrual proxy Contrarily, the modified Jones model proposed by Dechow et al. (1995) assumes that all increases in credit sales are driven by managerial opportunistic decisions and classifies them as discretionary, modifying the Jones model by removing the change in receivables from the change in sales. Dechow et al. (1995) show that their modification ameliorates the tendency of the Jones model to measure abnormal accruals with error when discretion is exercised over revenues. Therefore, by using both the Jones and modified Jones models, we are able to analyse a proxy for manipulation capturing only 'pure' accounting manipulation (that is, the Jones model), and a proxy that pools together accounting and real activities manipulation (the modified Jones model). Finally, we employ the Kasznik (1999) model, which dif fers from the modified Jones model in that it incorporates the change in operating cash flow as an explanatory variable to account for the negative correlation between accruals and cash flows (Dechow, 1994).

To obtain a measure of abnormal working capital accruals for all firms in industry $j$ for year $t$, we estimate the Kasznik model cross-sectionally for all industry-year combinations with at least six observations of data, as follows:

$$
\frac{W C A_{t}}{T A_{t-1}}=\alpha_{0}\left[\frac{1}{T A_{t-1}}\right]+\alpha_{1}\left[\frac{\Delta R E V_{t}}{T A_{t-1}}\right]+\alpha_{2}\left[\frac{\Delta C F O_{t}}{T A_{t-1}}\right]+\varepsilon_{t}
$$

\footnotetext{
${ }^{8}$ An alternative explanation is that ex-post failed firms with large ex-ante failure probability do not have scope to manage accruals given their extremely deteriorated financial condition.
}

where, $W C A$ is working capital accruals, $\triangle R E V$ is change in sales, $\triangle C F O$ is change in cash flow from operations and $T A$ are total assets, and $t$ is the timeperiod indicator. Next, for each firm, we calculate abnormal working capital accruals $(A W C A)$ as follows:

$$
\begin{aligned}
A W C A_{t} & =\frac{W C A_{t}}{T A_{t-1}} \\
& -\left(\hat{\alpha}_{0}\left[\frac{1}{T A_{t-1}}\right]+\hat{\alpha}_{1}\left[\frac{\Delta R E V_{t}-\Delta R E C_{t}}{T A_{t-1}}\right]+\hat{\alpha}_{2}\left[\frac{\Delta C F O_{t}}{T A_{t-1}}\right]\right)
\end{aligned}
$$

where, $\hat{\alpha}_{0}, \hat{\alpha}_{1}$ and $\hat{\alpha}_{2}$ are the fitted industry-coefficients from equation (1) and $\triangle R E C$ is the change in accounts receivable. To run models (1) and (2), all available observations are used, including continuing and failed firms, to avoid introducing biases in the analysis. By removing the change in receivables $(\triangle R E C)$ from the change in revenues in equation (2) the model classifies as discretionary accruals all changes in receivables, including those driven by the manipulation of real activities.

To obtain abnormal accruals measures using the modified Jones model, we use the same procedure, but we do not include $\triangle C F O$ as an additional variable in models (1) and (2). Finally, to estimate abnormal accruals using the original Jones model, we follow this last procedure (i.e. exclude $\triangle C F O$ from the models), but without subtracting change in accounts receivable from change in sales in the second step. The Jones model measures discretionary accruals not including the effect of real activities manipulation, as it classifies all changes in accounts receivables as 'normal' accruals.

\subsubsection{Classification of observations}

A key issue in our analysis of earnings manipulation by ex-post bankrupt firms is whether their attempts at masking poor performance in the years prior to failure were successful, and whether managers were able to mislead investors. To analyse if the accruals manipulation was successful at hiding poor performance we split sample observations in accordance to their ex-ante failure probability. Expost bankrupt firms that ex-ante do not show signs of failure are expected to have engaged in more aggressive accounting practices (Rosner, 2003), or at least, in practices that successfully masked poor performance. ${ }^{8}$ To identify them, we calculate the ex-ante one-year-ahead probability of bankruptcy of all failed firms. We use the Charitou et al., (2004) failure prediction model, which is built using the logit methodology. The model is as follows:

$$
P_{j t}(Y=1)=\frac{1}{\left(1+e^{-z}\right)}
$$


where,

$$
\begin{gathered}
-\mathrm{z}=-7.1786+12.3826 * \frac{\text { Total Liabilities }_{\mathrm{jt}}}{\text { Total Assets }_{\mathrm{jt}}}- \\
20.9691 * \frac{\text { EBIT }_{\mathrm{jt}}}{\text { Total Liabilities }_{\mathrm{jt}}}-3.0174 * \frac{\mathrm{CFO}_{\mathrm{j} 1}}{\text { Total Liabilities }_{\mathrm{jt}}}
\end{gathered}
$$

where, $P_{j t}(Y=1)$ is the probability of failure for entity $j$ at the end of year $t$; EBIT is earnings before interest and taxes; and $C F O$ is cash flows from operations. Using this method, we obtain an ex-ante probability that the firm would end up being bankrupt that we use to identify firms that are suspect of more aggressive earnings practices. ${ }^{9}$

\subsection{Measurement of real earnings manipulation}

To analyse the existence of real activities manipulation we focus on one specific type of real earnings management: sales manipulation, which we measure following the method of Roychowdhury (2006). Similar to the calculation of abnormal accruals in equations (1) and (2), the first stage consists of deriving normal cash flow activity. We run the following cross-sectional regression for every industry-year combination with at least six observations of data:

$$
\frac{C F O_{t}}{T A_{t-1}}=\beta_{0}\left[\frac{1}{T A_{t-1}}\right]+\beta_{1}\left[\frac{R E V_{t}}{T A_{t-1}}\right]+\beta_{2}\left[\frac{\Delta R E V_{t}}{T A_{t-1}}\right]+e_{n}
$$

where all variables are defined as before. For every observation, abnormal cash flow ( $A C F O$ ) is obtained by subtracting from actual firm $C F O$ the normal $C F O$ calculated using the estimated $\hat{\beta}$ coefficients from equation (4). The procedure is the same as the one previously explained for estimating a firm' $\mathrm{s}$ abnormal accruals. Once $A C F O$ has been estimated, we adapt the method by Roychowdhury (2006) to compare cash flow be-

\footnotetext{
${ }^{9}$ We do not use Altman's (1968) Z-score model because it is built using LDA, a technique that makes strong demands on the structure of data. First, it requires that the financial ratios are normally distributed. This is known not to be the case (Ezzamel and Mar Molinero, 1987). Also, the ratios of failed companies should have the same variance-covariance structures as those of continuing firms. Richardson and Davidson $(1983 ; 1984)$ show this assumption does not hold in the context of failure prediction. Furthermore, we do not use a model developed with US data for UK firms since there are significant differences between the reporting practices and insolvency codes of the two countries (Charitou et al., 2004). Finally , Mensah (1984) finds distress prediction models to be fundamentally unstable: coef ficients varying according to the underlying health of the economy. Thus model derivation should be as close in time as possible to the period over which predictions are made.

${ }^{10}$ We do not use the Basu (1997) model as F AME does not provide share prices for most of our sample of bankrupt firms. In addition, several studies including Dietrich et al., (2007) recommend the use of non-market-based versions of Basu specifications, such as the ones in Ball and Shivakumar (2005)
}

haviour in suspect firms - in our case, the failed firms - with the sample of continuing firms as follows:

$$
A C F O_{t}=\delta_{0}+\delta_{1} \text { SIZE }_{t-1}+\delta_{2} \text { NetIncome }_{t}+\delta_{3} \text { FAILING }_{t}+\tau_{t}
$$

where SIZE is defined as the natural logarithm of total assets, NetIncome is net income scaled by beginning-of-period total assets, and FAILING is a dummy indicator taking the value of 1 if the firm goes bankrupt; 0 otherwise, and $t$ is the time-period indicator. If failed firms manipulate sales upwards by offering more lenient credit terms, then it is expected that the level of cash flow will be abnormally low, given the level of sales. Thus, if failed firms are manipulating their sales, $\delta_{3}$ will be negative and significant, consistent with an abnormally low level of $C F O$, given the reported sales.

\subsection{Measurement of conditional conservatism}

Both accounting accruals and real activities manipulation are likely to result in a reduction of timely loss recognition in failed firms. To measure the dif ferential recognition speed of economic gains and losses in earnings we use the time series and accruals-based measures of conditional conservatism developed by Ball and Shivakumar (2005).

\subsubsection{Time series tests based on the persistence of income changes}

Basu (1997) and Ball and Shivakumar (2005) argue that the asymmetric recognition of economic gains and losses in earnings leads to differences in the persistence of gains and losses. Losses are less persistent as their timely recognition makes them appear as one-time shocks to earnings, while gains are reflected only when cash flows are realised, and, consequently, they are seen as permanent earnings components. This leads Basu (1997: 20) to argue that 'negative earnings changes have a greater tendency to reverse in the following period than positive earnings changes'. The tendency of negative earnings changes to reverse is documented by Brooks and Buckmaster (1976) and Elgers and Lo (1994).

Using the Basu (1997) method as a starting point, ${ }^{10}$ Ball and Shivakumar (2005) develop a model to measure timely incorporation of gains and losses in accounting income 'as the tendency for increases and decreases in earnings to reverse' (p. 92). We follow Ball and Shivakumar (2005) and estimate the following model for our full sample:

$$
\begin{aligned}
\Delta \text { NetIncome }_{t} & =\phi_{0}+\phi_{1} \text { DNetIncome }_{t-1}+\phi_{2} \Delta \text { NetIncome }_{t-1} \\
& +\phi_{3} \text { DNetIncome }_{t-1} * \Delta \text { NetIncome }_{t-1} \\
& +\sum \psi_{t} \text { Year }+\zeta_{t}
\end{aligned}
$$


where $\Delta$ NetIncome $_{t}\left(\Delta\right.$ NetIncome $\left._{t-1}\right)$ is change in net income from fiscal year $t-1$ to $t(t-2$ to $t-1)$, scaled by beginning-of-period total assets.

DNetIncome is a dummy variable that takes the value of 1 if the prior-year change in net income is negative; 0 otherwise. Year is a dummy variable for the fiscal year.

As described by Ball and Shivakumar (2005: 92), 'if gains are recognised in an untimely (smoothed) manner, they will be persistent components of net income that tend not to reverse and thus, $\phi_{2}$ will be equal to zero'. That is, under conservative accounting, they expect $\phi_{2}=0$. If managers choose aggressive accounting methods and foster good news recognition, positive income changes will behave as 'temporary earnings components that tend to reverse'. In our setting, where we compare ex-post failed with continuing firms, we expect that the $\phi_{2}$ coefficient will equal zero for continuing firms, as they will be conditionally conservative as required by accounting standards. However, for ex-post failed firms it will be significantly negative $\left(\phi_{2}<0\right)$ if they engage, as expected, in income-increasing accounting practices to conceal poor performance and postpone bankruptcy. Regarding economic losses, their timely recognition implies that 'they are recognised as transitory income decreases, and hence reverse' (Ball and Shivakumar, 2005: 92). As they show, the implication is that $\phi_{3}$ will be negative. However, given that failed firms engage in aggressive accounting policies $\left(\phi_{2}<0\right)$, in our setting we expect failed firms to show a significantly positive $\phi_{3}\left(\phi_{3}>0\right)$ if they delay the recognition of economic losses to the point that economic gains are reflected in earnings faster than economic losses. A positive $\phi_{3}$ implies economic losses are more persistent than economic gains. That is, firms deviate from conservative accounting and recognise losses in earnings at a slower pace than gains.

\subsubsection{Accruals-based tests}

As developed in Ball and Shivakumar (2005), asymmetric gain and loss recognition results in an asymmetry in accruals, 'because economic losses are more likely to be recognised on a timely basis as unrealised (i.e. non-cash) accrued char ges against income. Economic gains are more likely to be recognised when realised, and hence accounted for on a cash basis.' (p. 94). As a final test, following Ball and Shivakumar (2005) we estimate the model:

$$
\begin{aligned}
T A C C_{t} & =\gamma_{0}+\gamma_{1} D C_{t}+\gamma_{2} C F O_{t}+\gamma_{3} D C_{t}{ }^{*} C F O_{t} \\
& +\sum \psi_{t} \text { Year }+v_{\sharp}
\end{aligned}
$$

where $T A C C$ is total accruals divided by beginning of period total assets; $C F O$ is cash flow from operations divided by beginning-of-period total as- sets; $D C$ is a dummy variable that takes the value of 1 if $C F O$ is negative, and 0 otherwise. Year is a dummy variable for the fiscal year. Given that Dechow (1994) and Dechow et al. (1998) document a negative relation between accruals and cash flows, and that this negative relation is embedded in the very same nature of the accounting process (accruals reverse), Ball and Shivakumar (2005) expect a negative $\gamma_{2}$, reflecting the negative association between accruals and cash flows. Ball and Shivakumar (2005: 94) predict a positive $\gamma_{3}$ under the hypothesis that accrued losses are more likely when the firm presents negative cash flows. That is, under conditional conservatism, in the case of economic losses, the decrease in earnings and the decrease in cash flows happen in the same period, and, consequently, the negative correlation between accruals and cash flows decrease in bad news periods. This is captured by a positive $\gamma_{3}$. Our prediction is that failed firms have lower quality earnings than continuing firms, and therefore, are less likely to recognise losses as transitory items. This implies lower asymmetry, and thus, $\gamma_{3}$ is expected to be lower for failed firms. In the case of aggressive accounting, $\gamma_{3}$ would be negative. If managers manipulate earnings upwards (by releasing negative accruals or decreasing cost of goods sold) this would increase the negative association between accruals and cash flows, even in bad news periods, contributing to a negative $\gamma_{3}$ (aggressive accounting). If managers engage in real earnings management, and increase sales (and therefore, debtors) but not cash flows, this would again translate into creating more positive accruals in periods of negative cash flows, again contributing to a negative association between accruals and cash flows even in bad news periods, that is, to a negative $\gamma_{3}$. Consequently, income-increasing strategies, both through accounting or real earnings manipulation, lead to a negative $\gamma_{3}$ coefficient. ${ }^{11}$

Accrual behaviour in years of positive cash flows is expected to be different in failed and continuing firms too. If managerial behaviour in failed firms results in accruals manipulation to increase earnings, this would translate into earnings capturing economic gains faster, and thus, the negative association between cash flows and accruals would be reduced. Consequently, we expect a neg-

\footnotetext{
${ }^{11}$ Exogenous economic events may contribute as well to this negative $\gamma_{3}$ coefficient. An example of these economic events would be if a major customer suddenly slows down payment without any sales management involved, leading to lower cash flows as compared to sales. The firm may decide not to make a provision against this slower payment. If the firm ran into a cash flow crisis, we would also observe a negative association between cash flows and accruals in the model, a symptom of aggressive accounting. Thus, the model captures cases of aggressive accounting, regardless of the origin and motive of the underlying economic events.
} 
Table 1

Sample selection procedure and distribution of observations

Panel A: Sample selection procedure

Firms with data available in FAME entering bankruptcy 1998-2004

Less: Firms with less than three years of data previous to bankruptcy

Finance, real estate and insurance firms

Duplicated firms

Firms with missing data to calculate abnormal accruals

Failed firms with data to run earnings management tests

Continuing firms with full data available in F AME 1995-2004

Firm-years

Firms

$1,068 \quad 352$

(49)

(63)

834

14,742

Panel B: Distribution of failed firms by type of failur e

\begin{tabular}{lcccc} 
& Administration & Liquidation & Receivership & Total \\
\hline $\begin{array}{l}\text { Number of firms } \\
\text { (proportion) }\end{array}$ & 77 & 110 & 81 & 268 \\
$\begin{array}{l}\text { Number of firm-years } \\
\text { (proportion) }\end{array}$ & $(28.73 \%)$ & $(41.04 \%)$ & $(30.23 \%)$ & 834 \\
(28.06\%) & 331 & $(39.69 \%)$ & $(32.25 \%)$ &
\end{tabular}

Notes

Failed firms are obtained from the FAME 'inactive companies' file. Abnormal Accruals are abnormal working capital accruals as calculated using the Kasznik (1999) model.

ative coef ficient on $\gamma_{2}$ for failed and continuing firms, but smaller in absolute value for failed firms.

\subsection{Sample selection procedure}

Financial statement data are collected from the FAME database. FAME contains detailed information on public (quoted at either the London Stock Exchange's Primary Market or at the Alternative Investment Market (AIM)) and private firms in the UK and Ireland. All British publicly quoted firms included in the database 'Active company file' at the time of data collection entered our continuing sample. Where available, we collected data for these firms as far back as 1990 . The continuing sample with full data available consists of 2,801 firms.

UK publicly quoted firms that received an administration order, went into receivership, or were liquidated, as per the Insolvency Act 1986, were identified from the FAME database 'Inactive company file'. ${ }^{12}$ Furthermore, for a failed firm to qualify for our sample, it had to declare insolvency between 1998 and 2004, and to have at least three years of full financial data prior to its collapse. We exclude finance, insurance and real estate firms (division H, 60-67, of US SIC code system), as firms operating in these industries are structurally different and their financial reporting practices generally preclude combining them with non-financial firms (Gilbert et al., 1990). We also exclude duplicates and observations with missing data to run our earnings management tests.

These criteria result in 268 failed firms with full data available. From those, 77 went into administration, 81 into receivership, and 110 were liquidations. We cannot distinguish between firms in the main market and AIM as once firms become inactive FAME classifies them as 'Quoted Inactive'. Table 1 summarises the sample selection procedure and provides a classification of observations across types of failure. ${ }^{13}$

\section{Empirical results}

\subsection{Accruals manipulation in failed vs. continuing firms}

Using the method described in Section 3.1.1 above, we first classify failed firm-year observations that have an ex-ante probability of failure lower than $15 \%$ as having a low probability

\footnotetext{
${ }^{12}$ From the 'Inactive company' file we choose companies registered in the UK, and select 'public companies' ('legal form') including only receiverships, administrations and liquidations. To confirm the nature of the failure and its formal date we look at announcements from other sources (e.g. press announcements). The list of failed firms is available from the authors upon request.

${ }^{13}$ Auditors play a significant role in ensuring financial statement quality, reducing the incidence of earnings management (Becker et al., 1998) and opportunistic loss deferrals (Chung et al., 2003). We do not consider the monitoring role of auditors in our study due to insuf ficient data. Out of our sample of failed firms, 25 observations received a qualified opinion (19 of them in $t-1), 277$ an unqualified opinion and for all others data were not available. The year prior to bankruptcy, $10.1 \%$ of failed firms received a qualified opinion, while $39.7 \%$ received an unqualified opinion and no data were available for the remaining firms.
} 
Table 2

Descriptive statistics of sample firms

Panel A: Continuing firms $(\mathrm{N}=14,742)$

\begin{tabular}{lrrrrrrr} 
& Mean & Median & Std. Dev & Q1 & Q3 & Min. & Max. \\
\hline Size & 9.686 & 9.272 & 2.202 & 8.031 & 10.978 & 6.099 & 15.878 \\
Revenue & 2.098 & 1.650 & 3.005 & 0.958 & 2.685 & 0.054 & 8.676 \\
Net income & 0.026 & 0.043 & 0.779 & 0.001 & 0.097 & -0.715 & 0.487 \\
Cash flow & 0.071 & 0.092 & 0.654 & 0.002 & 0.180 & -0.932 & 0.675 \\
Total accruals & -0.045 & -0.055 & 0.606 & -0.119 & 0.013 & -0.551 & 0.694 \\
Working cap. accruals & 0.003 & -0.017 & 0.434 & -0.067 & 0.047 & -0.498 & 0.739 \\
Abnormal accruals & 0.003 & 0.001 & 0.167 & -0.037 & 0.041 & -0.334 & 0.333 \\
Failure probability & 0.361 & 0.127 & 0.403 & 0.004 & 0.821 & 0.000 & 1.000
\end{tabular}

Panel B: HighP failed firms $(\mathrm{N}=612)$

\begin{tabular}{lrrrrrrr} 
& Mean & Median & Std. Dev & \multicolumn{1}{c}{ Q1 } & Q3 & Min. & Max. \\
\hline Size & 8.777 & 8.516 & 1.536 & 7.665 & 9.553 & 6.441 & 14.314 \\
Revenue & 2.585 & 2.234 & 1.705 & 1.506 & 3.291 & 0.303 & 9.103 \\
Net income & -0.060 & 0.001 & 0.231 & -0.074 & 0.036 & -1.155 & 0.219 \\
Cash flow & 0.007 & 0.035 & 0.239 & -0.063 & 0.115 & -1.025 & 0.450 \\
Total accruals & -0.066 & -0.073 & 0.197 & -0.149 & 0.015 & -0.815 & 0.447 \\
Working cap. accruals & -0.014 & -0.023 & 0.192 & -0.093 & 0.063 & -0.539 & 0.529 \\
Abnormal accruals & -0.036 & -0.027 & 0.113 & -0.076 & 0.013 & -0.391 & 0.204 \\
Failure probability & 0.781 & 0.910 & 0.259 & 0.617 & 0.991 & 0.165 & 1.000
\end{tabular}

Panel C: LowP failed firms $(\mathrm{N}=\mathbf{2 2 2})$

\begin{tabular}{lrrrrrrr} 
& Mean & Median & Std. Dev & \multicolumn{1}{c}{ Q1 } & Q3 & Min. & Max. \\
\hline Size & 8.982 & 8.870 & 1.736 & 7.671 & 10.059 & 5.767 & 14.259 \\
Revenue & 2.619 & 1.946 & 2.111 & 1.285 & 3.531 & 0.073 & 11.756 \\
Net income & 0.071 & 0.063 & 0.204 & 0.014 & 0.119 & -0.526 & 0.707 \\
Cash flow & 0.123 & 0.117 & 0.283 & 0.012 & 0.211 & -0.803 & 1.094 \\
Total accruals & -0.051 & -0.068 & 0.211 & -0.140 & 0.013 & -0.475 & 0.657 \\
Working cap. accruals & -0.001 & -0.017 & 0.205 & -0.085 & 0.059 & -0.411 & 0.687 \\
Abnormal accruals & 0.017 & 0.001 & 0.118 & -0.052 & 0.066 & -0.309 & 0.394 \\
Failure probability & 0.030 & 0.009 & 0.040 & 0.001 & 0.051 & 0.000 & 0.136
\end{tabular}

Notes

$\operatorname{High} P(\operatorname{Low} P)$ are failed firms with a high (low) ex-ante probability of failure. A high (low) probability is set up as being higher or equal (lower) than $15 \%$.

Size is the natural logarithm of total assets. All other variables are scaled by beginning-of-period total assets:

Revenue is sales. Working Cap Accruals is working capital accruals. Failure Probability is the probability that a firm will go bankrupt calculated as in Charitou et al. (2004). Abnormal Accruals is a measure of firm abnormal working capital accruals calculated using the Kasznik (1999) model. Firms are classified as (1)Continuing if they do not go bankrupt during the considered period (1998-2004), (2) Failed (LowP) if they go bankrupt and their ex-ante bankruptcy probability of going bankrupt is below 15\%; or (3) Failed (HighP) if they go bankrupt and their ex-ante bankruptcy probability of going bankrupt is equal or above $15 \%$.

$(L o w P)$ of failure, and all others as having a high probability $($ HighP $)$ of failure. ${ }^{14}$

Table 2 presents descriptive statistics of sample firms. Continuing firms have a median (mean)

\footnotetext{
${ }^{14}$ Observations are classified almost identically if we increase the threshold of failure to $20 \%$ or even $25 \%$.

${ }_{15}$ Throughout the text we make reference to HighP and LowP firms for simplicity. It would be more correct to use the terms HighP and LowP firm-year observations.
}

probability of bankruptcy of $12.7 \%(36.1 \%)$. Failed firms are split between LowP and HighP firm-year observations. ${ }^{15}$ HighP firms have a median (mean) probability of bankruptcy of $91.0 \%$ (78.1\%), whilst LowP firms have a probability of $1 \%(3 \%)$. A more detailed look at the descriptive statistics reveals that LowP firms have higher net income $(N I)$ and cash from operations $(C F O)$ than both continuing and HighP firms. Interestingly, HighP firms have, on average, higher sales relative 
Table 3

Descriptive statistics of failed firms by year of bankruptcy

Panel A: $t-4$

\begin{tabular}{lrrrrrrrr} 
& \multicolumn{3}{c}{ LowP failed firms } & \multicolumn{3}{c}{ HighP failed firms } & \multicolumn{2}{c}{$p$-value difference } \\
& Mean & Median & Std. Dev & Mean & Median & Std. Dev & Mean & Medians \\
\hline Size & 8.654 & 8.137 & 1.438 & 9.471 & 9.416 & 1.034 & $(0.18)$ & $(0.13)$ \\
Revenue & 1.183 & 1.082 & 0.921 & 2.098 & 1.878 & 1.405 & $(0.13)$ & $(0.19)$ \\
Net income & 0.025 & 0.013 & 0.083 & -0.001 & 0.006 & 0.026 & $(0.26)$ & $(0.45)$ \\
Cash flow & 0.064 & 0.103 & 0.082 & 0.110 & 0.121 & 0.104 & $(0.24)$ & $(0.27)$ \\
Total accruals & -0.039 & -0.059 & 0.062 & -0.112 & -0.114 & 0.090 & $(0.09)$ & $(0.19)$ \\
Working cap. accruals & -0.007 & -0.037 & 0.064 & -0.040 & -0.038 & 0.039 & $(0.20)$ & $(0.27)$ \\
Failure probability & 0.014 & 0.003 & 0.023 & 0.612 & 0.606 & 0.259 & $(0.00)$ & $(0.01)$
\end{tabular}

Panel B: $t-3$

\begin{tabular}{lrrrrrrrr} 
& \multicolumn{3}{c}{ LowP failed firms } & \multicolumn{3}{c}{ HighP failed firms } & \multicolumn{2}{c}{$p$-value difference } \\
& Mean & Median & Std. Dev & Mean & Median & Std. Dev & Mean & Medians \\
\hline Size & 9.269 & 9.259 & 1.484 & 8.797 & 8.249 & 1.654 & $(0.03)$ & $(0.01)$ \\
Revenue & 2.675 & 1.958 & 2.184 & 2.823 & 2.228 & 1.953 & $(0.33)$ & $(0.10)$ \\
Net income & 0.098 & 0.073 & 0.234 & 0.001 & 0.011 & 0.084 & $(0.00)$ & $(0.01)$ \\
Cash flow & 0.174 & 0.134 & 0.304 & 0.030 & 0.024 & 0.134 & $(0.00)$ & $(0.01)$ \\
Total accruals & -0.076 & -0.079 & 0.164 & -0.029 & -0.032 & 0.140 & $(0.03)$ & $(0.02)$ \\
Working cap. accruals & -0.023 & -0.021 & 0.160 & 0.014 & 0.006 & 0.140 & $(0.06)$ & $(0.03)$ \\
Failure probability & 0.030 & 0.006 & 0.042 & 0.742 & 0.847 & 0.269 & $(0.00)$ & $(0.00)$
\end{tabular}

Panel C: $t-2$

\begin{tabular}{lrrrrrrrr} 
& \multicolumn{3}{c}{ LowP failed firms } & \multicolumn{3}{c}{ HighP failed firms } & \multicolumn{2}{c}{$p$-value difference } \\
& Mean & Median & Std. Dev & Mean & Median & Std. Dev & Mean & Medians \\
\hline Size & 9.070 & 8.964 & 1.804 & 8.923 & 8.673 & 1.558 & $(0.28)$ & $(0.26)$ \\
Revenue & 2.436 & 1.834 & 1.623 & 2.592 & 2.396 & 1.346 & $(0.25)$ & $(0.08)$ \\
Net income & 0.087 & 0.049 & 0.190 & -0.030 & 0.003 & 0.124 & $(0.00)$ & $(0.00)$ \\
Cash flow & 0.160 & 0.137 & 0.257 & 0.039 & 0.064 & 0.143 & $(0.00)$ & $(0.00)$ \\
Total accruals & -0.073 & -0.075 & 0.149 & -0.069 & -0.080 & 0.113 & $(0.40)$ & $(0.46)$ \\
Working cap. accruals & -0.024 & -0.021 & 0.152 & -0.020 & -0.030 & 0.115 & $(0.41)$ & $(0.47)$ \\
Failure probability & 0.033 & 0.010 & 0.044 & 0.742 & 0.907 & 0.288 & $(0.00)$ & $(0.00)$
\end{tabular}

Panel D: $t-1$

\begin{tabular}{lrrrrrrrr} 
& \multicolumn{3}{c}{ LowP failed firms } & \multicolumn{3}{c}{ HighP failed firms } & \multicolumn{2}{c}{$p$-value difference } \\
& Mean & Median & Std. Dev & Mean & Median & Std. Dev & Mean & Medians \\
\hline Size & 8.977 & 8.782 & 1.967 & 8.813 & 8.597 & 1.458 & $(0.25)$ & $(0.39)$ \\
Revenue & 2.272 & 1.636 & 1.781 & 2.376 & 1.999 & 1.659 & $(0.35)$ & $(0.14)$ \\
Net income & 0.015 & 0.021 & 0.209 & -0.106 & -0.040 & 0.192 & $(0.00)$ & $(0.00)$ \\
Cash flow & 0.074 & 0.093 & 0.258 & 0.011 & 0.036 & 0.196 & $(0.03)$ & $(0.00)$ \\
Total accruals & -0.059 & -0.101 & 0.292 & -0.117 & -0.100 & 0.169 & $(0.04)$ & $(0.19)$ \\
Working cap. accruals & -0.015 & -0.042 & 0.283 & -0.065 & -0.053 & 0.172 & $(0.06)$ & $(0.27)$ \\
Failure probability & 0.041 & 0.021 & 0.045 & 0.865 & 0.966 & 0.211 & $(0.00)$ & $(0.01)$
\end{tabular}

Notes

$\operatorname{HighP}($ LowP) are failed firms with a high (low) ex-ante probability of failure. A high (low) probability is set up as being higher or equal (lower) than 15\%. Size is the natural logarithm of total assets. Revenue is sales. Working cap. accruals is working capital accruals. Failure probability is the probability that a firm will go bankrupt calculated as in Charitou et al. (2004). Abnormal accruals is a measure of firm abnormal working capital accruals calculated using the Kasznik (1999) model. Firms are classified as (1) Continuing if they do not go bankrupt during the considered period (1998-2004), (2)Failed (LowP) if they go bankrupt and their exante bankruptcy probability of going bankrupt is below 15\%; or (3) Failed (HighP) if they go bankrupt and their ex-ante bankruptcy probability of going bankrupt is equal or above $15 \%$. 
Table 4

Yearly differences in abnormal accruals

Panel A: $t-4$

\begin{tabular}{cccccccc} 
& $\begin{array}{c}\text { Expected } \\
\text { sign of } \\
\text { difference }\end{array}$ & $\begin{array}{c}\text { LowP vs. HighP } \\
\text { Mean }\end{array}$ & $\begin{array}{c}\text { Ledian } \\
\text { (p-value) }\end{array}$ & $\begin{array}{c}\text { LowP vs. Cont } \\
\text { (p-value) }\end{array}$ & \multicolumn{2}{c}{ Failed vs. Cont } \\
(p-value) & Median & Mean & Median \\
(p-value) & (p-value) & (p-value) \\
\hline Abnormal accruals & $(+)$ & 0.07 & 0.02 & 0.02 & 0.02 & 0.01 & 0.01 \\
& & $(0.01)$ & $(0.00)$ & $(0.05)$ & $(0.07)$ & $(0.91)$ & $(0.92)$
\end{tabular}

Panel B: $t-3$

\begin{tabular}{|c|c|c|c|c|c|c|c|}
\hline & \multirow{2}{*}{$\begin{array}{l}\text { Expected } \\
\text { sign of } \\
\text { difference }\end{array}$} & \multicolumn{2}{|c|}{ LowP vs. HighP } & \multicolumn{2}{|c|}{ LowP vs. Cont } & \multicolumn{2}{|c|}{ Failed vs. Cont } \\
\hline & & $\begin{array}{c}\text { Mean } \\
\text { (p-value) }\end{array}$ & $\begin{array}{l}\text { Median } \\
\text { (p-value) }\end{array}$ & $\begin{array}{c}\text { Mean } \\
\text { (p-value) }\end{array}$ & $\begin{array}{l}\text { Median } \\
\text { (p-value) }\end{array}$ & $\begin{array}{c}\text { Mean } \\
\text { (p-value) }\end{array}$ & $\begin{array}{c}\text { Median } \\
\text { (p-value) }\end{array}$ \\
\hline bnor & $(+)$ & $\begin{array}{c}0.05 \\
(0.00)\end{array}$ & $\begin{array}{c}0.04 \\
(0.01)\end{array}$ & $\begin{array}{c}0.02 \\
(0.09)\end{array}$ & $\begin{array}{c}0.02 \\
(0.05)\end{array}$ & $\begin{array}{c}0.00 \\
(0.27)\end{array}$ & $\begin{array}{l}-0.01 \\
(0.10)\end{array}$ \\
\hline
\end{tabular}

Panel C: $t-2$

\begin{tabular}{|c|c|c|c|c|c|c|c|}
\hline & \multirow{2}{*}{$\begin{array}{l}\text { Expected } \\
\text { sign of } \\
\text { difference }\end{array}$} & \multicolumn{2}{|c|}{ LowP vs. HighP } & \multicolumn{2}{|c|}{ LowP vs. Cont } & \multicolumn{2}{|c|}{ Failed vs. Cont } \\
\hline & & $\begin{array}{c}\text { Mean } \\
\text { (p-value) }\end{array}$ & $\begin{array}{l}\text { Median } \\
\text { (p-value) }\end{array}$ & $\begin{array}{c}\text { Mean } \\
\text { (p-value) }\end{array}$ & $\begin{array}{l}\text { Median } \\
\text { (p-value) }\end{array}$ & $\begin{array}{c}\text { Mean } \\
\text { (p-value) }\end{array}$ & $\begin{array}{c}\text { Median } \\
\text { (p-value) }\end{array}$ \\
\hline Abnorn & $(+)$ & $\begin{array}{c}0.04 \\
(0.00)\end{array}$ & $\begin{array}{c}0.04 \\
(0.01)\end{array}$ & $\begin{array}{c}0.03 \\
(0.06)\end{array}$ & $\begin{array}{c}0.02 \\
(0.41)\end{array}$ & $\begin{array}{c}0.00 \\
(0.12)\end{array}$ & $\begin{array}{l}-0.01 \\
(0.19)\end{array}$ \\
\hline
\end{tabular}

Panel D: $t-1$

\begin{tabular}{|c|c|c|c|c|c|c|c|}
\hline & \multirow{2}{*}{$\begin{array}{l}\text { Expected } \\
\text { sign of } \\
\text { difference }\end{array}$} & \multicolumn{2}{|c|}{ LowP vs. HighP } & \multicolumn{2}{|c|}{ LowP vs. Cont } & \multicolumn{2}{|c|}{ Failed vs. Cont } \\
\hline & & $\begin{array}{c}\text { Mean } \\
\text { (p-value) }\end{array}$ & $\begin{array}{l}\text { Median } \\
\text { (p-value) }\end{array}$ & $\begin{array}{c}\text { Mean } \\
\text { (p-value) }\end{array}$ & $\begin{array}{c}\text { Median } \\
\text { (p-value) }\end{array}$ & $\begin{array}{c}\text { Mean } \\
\text { (p-value) }\end{array}$ & $\begin{array}{c}\text { Median } \\
\text { (p-value) }\end{array}$ \\
\hline bno & $(-)$ & $\begin{array}{l}-0.05 \\
(0.02)\end{array}$ & $\begin{array}{l}-0.04 \\
(0.00)\end{array}$ & $\begin{array}{l}-0.05 \\
(0.01)\end{array}$ & $\begin{array}{l}-0.05 \\
(0.02)\end{array}$ & $\begin{array}{l}-0.04 \\
(0.00)\end{array}$ & $\begin{array}{l}-0.03 \\
(0.00)\end{array}$ \\
\hline
\end{tabular}

Notes

Firms are classified as (1) Cont (continuing) if they do not go bankrupt during the period studied (1998-2004), (2) LowP if they go bankrupt and their ex-ante probability of failing is below $15 \%$; or (3) HighP if they go bankrupt and their ex-ante probability of failing is equal to or above $15 \%$. To compare failed and continuing firms, every failed firm-year is matched to the average abnormal accruals of continuing firms in the same industry and year.

Reported $p$-values are for a one-tail test of differences, calculated using a t-test for the means, and a Wilcoxon test for the medians.

Abnormal accruals are abnormal working capital accruals as measured by the Kasznik (1999) model.

to cash flow than both $L o w P$ and continuing firms. The difference in mean and median $C F O$ between these groups is significant at the $1 \%$ level using a $t$ - and a Wilcoxon-test, respectively, while the difference in median sales is significant at the $5 \%$ level ( $p$-value $=0.022$ ). This initial evidence is consistent with the sales manipulation hypothesis.

LowP firms have significantly higher AWCAs than HighP firms, suggesting that LowP firms are potentially more successful at hiding their distress from the market, and can therefore manage earnings more aggressively than the sub-set of HighP firms, which show more signs of being distressed. The difference in mean and median abnormal accruals between the HighP and LowP groups is sig- nificant at the $1 \%$ level, $(t=4.28$, and $Z=4.61)$.

Tables 3 and 4 analyse the evolution of key financial indicators during the years prior to bankruptcy for HighP and LowP firms. Extant research on bankruptcy suggests that significant differences exist between the accounting numbers of failed and non-failed firms up to five years before bankruptcy (Beaver, 1966). However, we expect that some firms (those classified as LowP) retain sufficient scope to manipulate their numbers, and thus, may successfully appear as healthy in the years prior to bankruptcy. Such successful manipulation could af fect the classification performance of bankruptcy models, especially for a great number of firms that lie in what Jones (1987) refers to as 
the 'grey' area.

Table 3, Panels A to D show the evolution of some basic financial indicators of LowP and HighP firms from four years prior to bankruptcy ( $t-4)$ until the year prior to the event $(t-1)$, where $t$ is the year of bankruptcy. In year $t-4$ the only relevant difference between LowP and HighP firms is on their ex-ante probability of failure. However , as bankruptcy approaches (years $t-3$ to $t-1$ ), LowP firms manage to stay more profitable (higher net income, cash flows and less negative accruals) than HighP firms. This evidence could be consistent with $\operatorname{LowP}$ firms successfully manipulating their earnings upwards prior to bankruptcy.

Table 4 analyses the evolution of abnormal accruals (calculated with the Kasznik, 1999 model), comparing LowP with continuing and HighP firms, as well as continuing firms with all failed firms grouped together . To compare failed and continuing firms, every failed firm-year is matched to the average abnormal accruals of continuing firms in the same industry and year. LowP firms are expected to manage earnings more aggressively than HighP and continuing firms. If they manipulate their earnings successfully in the years preceding bankruptcy, it is expected that in the fourth, third and second years before the failure event (i.e. $t-4$ to $t-2$ ) the dif ference in mean (median) AWCA will be positive. However , because these firms end up being bankrupt, there should be a reversal of the previously manipulated accruals in the year just before bankruptcy $(t-1)$, and thus, the dif ference in $A W C A$ should become negative in this last year. In accordance with our expectations, Table 4, Panels A to $\mathrm{C}$ show that the differences between LowP and HighP are significantly positive from $t-4$ to $t-2$. This is consistent with $L o w P$ firms manipulating earnings upwards in the years prior to failure. Also in line with our predictions, we can observe that the difference becomes negative the year just before bankruptcy $(t-1)$. The results of year $t-1$, with a larger reversal of accruals for LowP firms are consistent with larger income-increasing earnings management in prior years. These results also discard the alternative explanation for the existence of the relatively large number of LowP firms that these firms are not real failures but voluntary liquidations.

The dif ferences in AWCA between LowP and continuing firms presented in the middle column of Table 4 follow a similar pattern, albeit the significance is slightly lower . Overall, the evidence supports our hypothesis that managers of distressed companies engage in earnings management to conceal their poor performance and, as bankruptcy looms closer and no improvement in the situation is observed, they eventually exhaust their instruments for successful accrual manipulation, and an accumulation of bad news will be observed.
The last column of Table 4 shows the difference in $A W C A$ between all failed firms ( LowP and $H i g h P$ combined) and continuing firms. The differences are not significant except for $t-1$, where negative accruals accumulate both for Low $P$ and HighP firms. Thus, whilst LowP firms show signs of having aggressive accounting policies in place, HighP firms are likely to have exhausted their resources for successful manipulation, having average negative abnormal accruals (as shown on Table 2), compensating those of the LowP firms when all failed firms are pooled together These results might imply that HighP firms are being closely monitored by the market as obvious cases of distress companies, whilst the market might not monitor LowP firms as closely, permitting a higher degree of manipulation in these companies.

Our results are robust to the use of other models of discretionary accruals. Specifically, we use the modified Jones model (Dechow et al., 1995), and the original Jones (1991) model. The modified Jones model classifies all increases in debtors as discretionary accruals, consequently capturing both pure accounting manipulation and real activities manipulation. The Jones (1991) model captures only pure accounting manipulation, as it classifies all increases in debtors as normal accruals.

\subsection{Real activities manipulation}

Table 5, Panel A reports parameter estimates of running equation (4) to identify abnormally low cash flow levels relative to sales. We obtain results consistent with previous research by Roychowdhury (2006). ${ }^{16}$ Table 5, Panel B reports descriptive statistics of normal $(N C F O)$ and abnormal cash flow from operations $(A C F O)$. These descriptive statistics are also consistent with previous research. Table 5, Panel $\mathrm{C}$ reports results of running equation (5) for sample firms. In accordance with our predictions, $\quad \delta_{3}$ is significantly negative, consistent with failed firms having, on average, negative abnormal cash flows, given their reported levels of sales. HighP firms have the highest median level of sales of all firms in the sample (see Table 2); however, these sales do not create the expected level of cash flows. In fact, cash flows from operations in failed firms are abnormally low.

These results, combined with those of the prior section, provide some evidence consistent with the

\footnotetext{
${ }^{16}$ Whilst the calculation of abnormal accruals is a standard procedure in the literature, the calculation of abnormal cash flows $(A C F O)$ is not yet so. Thus, we provide the results of running equation (4) and descriptive statistics of $A C F O$ and NCFO. ACFO are calculated for the full sample of data available (20,049 observations) to avoid biasing the estimates of normal and abnormal CFO. Equation (5) is run for the set of firms with full data to run our earnings management tests (15,654 observations, see Table 1 for details).
} 
Table 5

Abnormal cash flow (ACFO) activity in failed firms

Panel A: Estimation of ACFO. Model parameters

\begin{tabular}{lccccc} 
& Intercept & $\beta_{1}$ & $\beta_{2}$ & Adj. R-sq & $\mathrm{N}$ \\
\hline Parameter & 0.0003 & 0.0711 & -0.0345 & 0.43 & 20,049 \\
$t$-stat & $(0.12)$ & $(3.09)$ & $(-0.50)$ & &
\end{tabular}

Panel B: Abnormal and normal CFO

\begin{tabular}{lcccccc} 
& Mean & Median & Std. Dev & Q1 & Q3 & N \\
\hline Abnormal CFO & 0.006 & 0.022 & 0.198 & -0.069 & 0.103 & 20,049 \\
Normal CFO & 0.074 & 0.063 & 0.079 & 0.029 & 0.109 & 20,049
\end{tabular}

Panel C: Comparison of failed (HighP) firms with the all other firms

\begin{tabular}{|c|c|c|c|c|c|c|}
\hline & Intercept & $\delta_{1}$ & $\delta_{2}$ & $\delta_{3}$ & Adj. R-sq & $\mathrm{N}$ \\
\hline $\begin{array}{l}\text { Parameter } \\
t \text {-stat }\end{array}$ & $\begin{array}{l}0.072 \\
(8.71)\end{array}$ & $\begin{array}{l}-0.001 \\
(-1.36)\end{array}$ & $\begin{array}{l}0.012 \\
(2.43)\end{array}$ & $\begin{array}{c}-0.083 \\
(-21.45)\end{array}$ & 0.23 & 15,654 \\
\hline
\end{tabular}

Notes

Panel A presents results of running equation (4) cross-sectionally:

$$
\frac{C F O_{t}}{T A_{t-1}}=\beta_{0}\left[\frac{1}{T A_{t-1}}\right]+\beta_{1}\left[\frac{R E V_{t}}{T A_{t-1}}\right]+\beta_{2}\left[\frac{\Delta R E V_{t}}{T A_{t-1}}\right]+e_{n}
$$

where, $C F O$ is cash flow from operations, $T A$ is total assets, and $R E V$ is total sales. There are 380 industry-year combinations from 1993 to 2003 with at least 6 observations per industry; the average industry-year group has 53 observations. This panel reports mean coefficients, $\mathrm{t}$-stats and $\mathrm{R}^{2}$ across all industry-years.

Panel B reports abnormal and normal CFO estimates. Abnormal CFO (ACFO) is obtained subtracting from actual CFO the expected or normal firm $\mathrm{CFO}$, which is obtained using the industry specific coef ficients derived from equation (4) above.

Panel C shows results of running equation (5) for sample firms

$$
A C F O_{t}=\delta_{0}+\delta_{1} S_{I Z E_{t-1}}+\delta_{2} N I_{t}+\delta_{3} \text { FAILING }_{t}+\tau_{t}
$$

where, SIZE is the natural logarithm of total assets, $N I$ is net income scaled by beginning-of-period total assets, and FAILING is a dummy indicator that takes the value of 1 if the firm goes bankrupt, 0 otherwise. Reported t-statistics are White (1980) heteroskedasticity consistent.

existence of potential preferences and trade-offs in choosing earnings management instruments. We show that HighP firms, having probably exhausted their opportunities for successful accrual (purely accounting) manipulation, resort to real actions that lead to an abnormal relation between cash flows and sales. This abnormal relation could be partly attributable to increases in sales through extended credit terms, beyond what could be considered 'normal' in the industry.

\subsection{Conditional conservatism in ex-post failed firms}

Results from tests of timely loss recognition using time-series tests ( $\mathrm{T}$ able 6 ) and accrualsbased tests (Table 7 ) are consistent with managers of failed firms engaging in pure accounting manipulation, and also in real activities manipulation to boost earnings. This translates into less condi- tionally conservative earnings.

Table 6 shows the results of running equation (6) for the sample of continuing firms, the whole sample of failed firms, and the three sub-samples of failed firms in years prior to failure ( $t-1, t-2$ and $t-3)$. The results show a distinct dif ferent behaviour between continuing and failed firms. As predicted by Ball and Shivakumar (2005), the $\phi_{2}$ coefficient of continuing firms, consistent with conditionally conservative accounting, is very close to zero and not significant. Timelier recognition of economic gains leads to a significantly negative $\phi_{2}$ coefficient. This is the case when we look at the failed firms. Also, if we look at the coef ficient capturing the recognition of economic losses $\left(\phi_{3}\right)$ we can see that, for continuing firms, the coefficient is, as expected, significantly negative showing the asymmetric nature of earnings and the more contemporaneous recognition of economic 
Table 6

Time series test of timeliness in loss r ecognition in continuing and failed firms

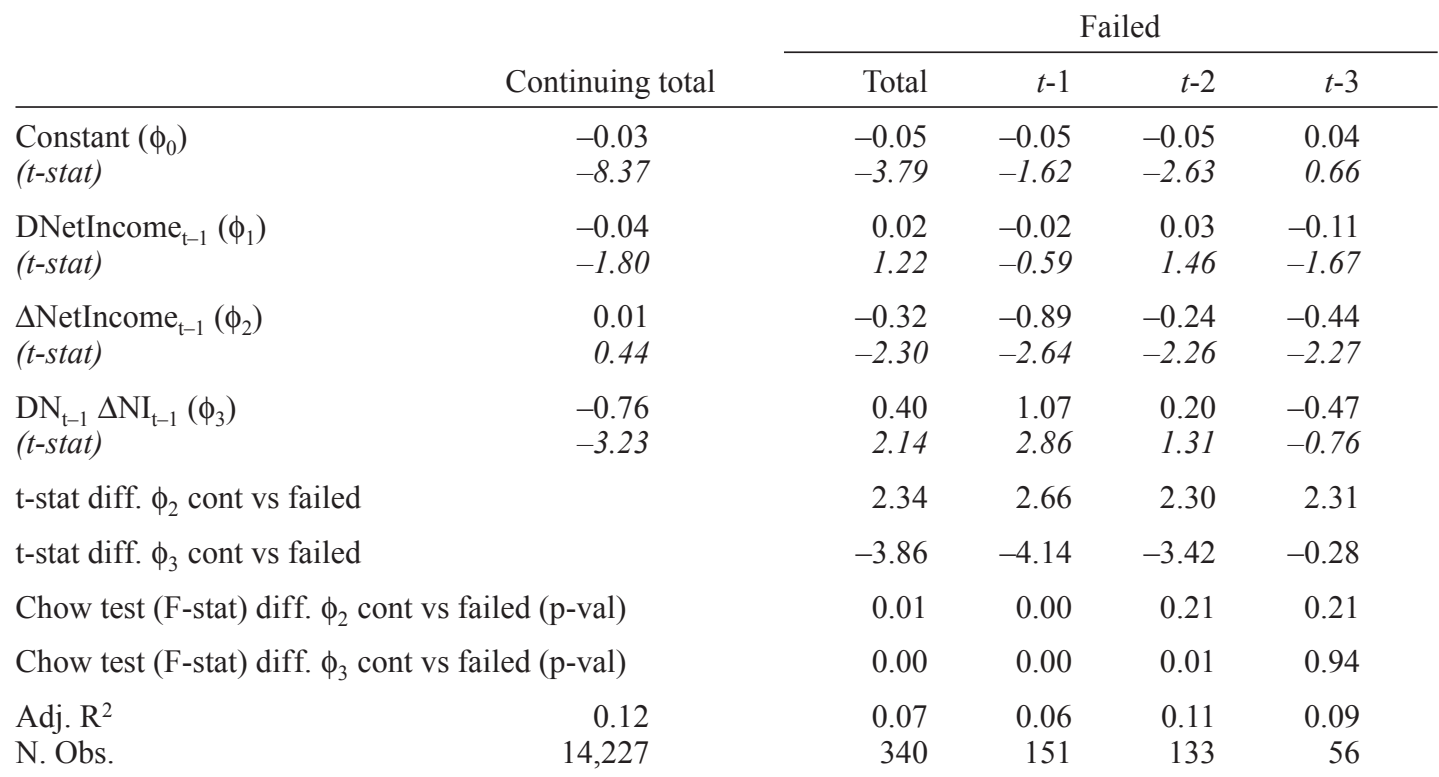

Notes

We run equation (6):

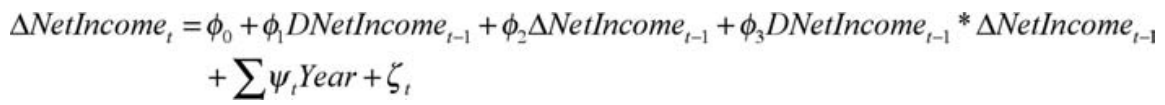

where $\Delta N I$ is change in net income from fiscal year t- 1 to $\mathrm{t}$, scaled by beginning-of-period total assets. $D N$ is a dummy variable that takes the value of 1 if the prior-year change in net income is negative; 0 otherwise. Year is a dummy variable for the fiscal year.

t-statistics are White (1980) heteroskedasticity-consistent.

We estimate the statistical significance of the differences between coefficients from different regressions using two procedures:

a) As in Giner and Rees (2001), we use the following statistic (distributed as a student t): $\theta_{1}-\theta_{2}$ divided by

$$
\sqrt{\sigma_{1}^{2}+\sigma_{2}^{2}}
$$

where $\theta_{i}$ is the estimated coefficient and $\sigma_{i}$ the standard error for variable $i$.

b) The more standard Chow (W ald) test. This specification is based on running a pooled regression with dummy variables to identify the different samples (in our case, failed vs continuing).As pointed out by Giner and Rees (2001 footnote 5) this approach assumes that the variance of the error across groups is the same.

losses than economic gains in earnings. However, there is again a shift in the sign of the coef ficient for failed firms, consistent with more aggressive accounting policies when financial health is in trouble. The difference in the $\phi_{2}$ and $\phi_{3}$ coefficients between continuing firms and the dif ferent sets of failed firms is significant at conventional levels in the first and second year before failure when we calculate the significance of the dif ference between failed and continuing firms using the approach in Giner and Rees (2001). When we use the more standard (and more restrictive) Chow test, we obtain similar results.
When we analyse economic gains and losses recognition in earnings by looking at the relation between accruals and cash flows (Table 7), we can see that, as predicted by Dechow (1994), Dechow et al. (1998) and Ball and Shivakumar (2005), there is a negative association between accruals and cash flows for all firms (negative and significant $\gamma_{2}$ ). Consistent also with our hypothesis of failed firms using more aggressive accounting, the $\gamma_{2}$ coefficient is significantly larger (smaller in absolute value) in failed than in continuing firms.

Finally, the $\gamma_{3}$ coefficient, capturing the asymmetry in the recognition of economic gains and losses in 
Table 7

Accruals-based test of loss recognition in continuing and failed firms

Failed

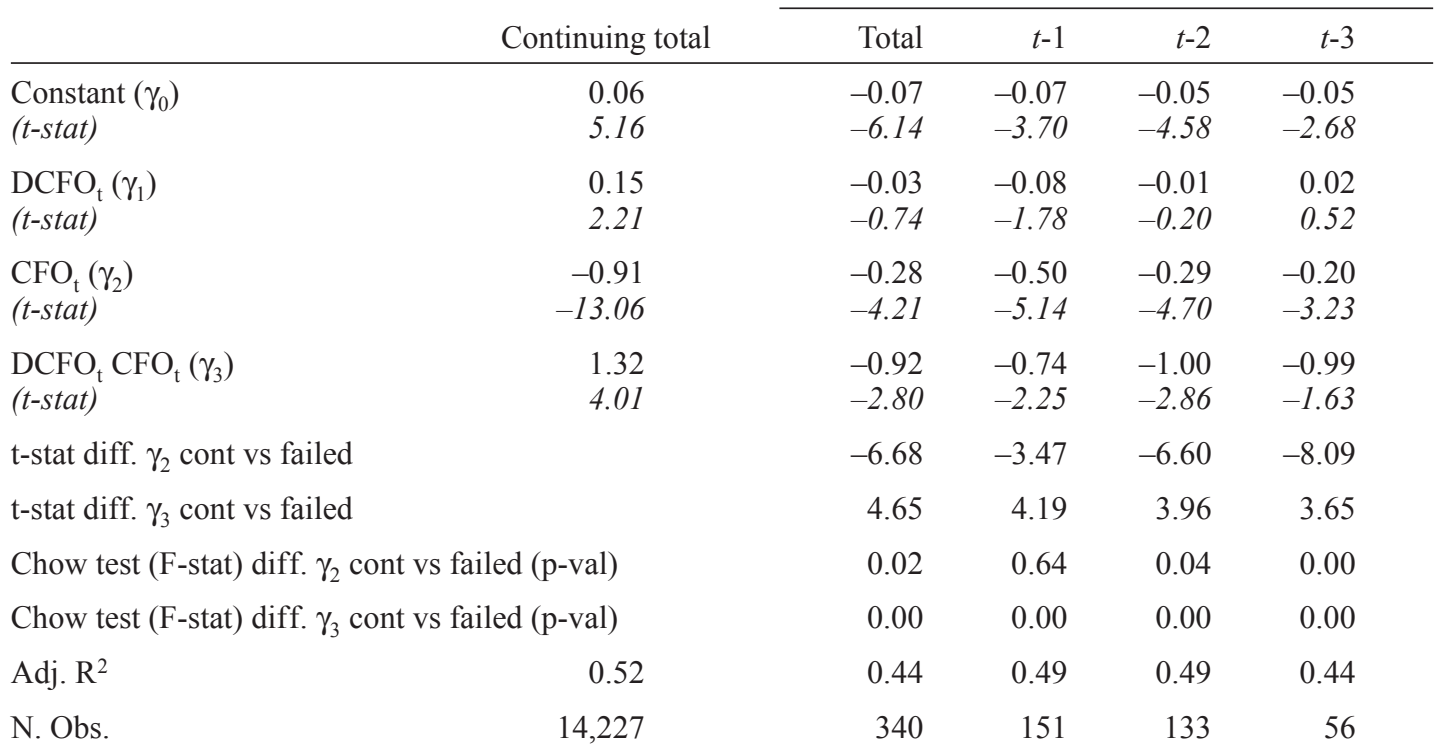

Notes

We run equation (7):

$$
T A C C_{t}=\gamma_{0}+\gamma_{1} D C_{t}+\gamma_{2} C F O_{t}+\gamma_{3} D C_{t} * C F O_{t}+\sum \psi_{t} \text { Year }+v_{t}
$$

where TACC is total accruals divided by beginning of period total assets; $C F O$ is cash flow from operations divided by beginning-of-period total assets; $D C$ is a dummy variable that takes the value of 1 if $C F O$ is negative, and 0 otherwise. Year is a dummy variable for the fiscal year.

t-statistics are White (1980) heteroskedasticity-consistent.

We estimate the statistical significance of the differences between coefficients from different regressions using two procedures:

a) As in Giner and Rees (2001), we use the following statistic (distributed as a student t): $\theta_{1}-\theta_{2}$ divided by

$$
\sqrt{\sigma_{1}^{2}+\sigma_{2}^{2}}
$$

where $\theta_{i}$ is the estimated coefficient and $\sigma_{i}$ the standard error for variable $i$.

b) The more standard Chow (W ald) test. This specification is based on running a pooled regression with dummy variables to identify the different samples (in our case, failed vs continuing).As pointed out by Giner and Rees (2001 footnote 5) this approach assumes that the variance of the error across groups is the same.

earnings is, consistent with conservative accounting, significantly positive for continuing firms. However, this is not the case for failed firms, where the coef ficient is significantly negative. This negative $\gamma_{3}$ coefficient is consistent with a

${ }^{17}$ Notice that the number of observations from Tables 6 and 7 differ slightly from the sample used for the earnings management tests due to data requirements to estimate models 6 (time series tests) and 7 (accruals-based tests). If we allow the sample to differ between Tables 6 and 7, we increase substantially the sample size to estimate model 7 (as we have more stringent data requirements for model 6, Table 6), obtaining up to 514 firm-year observations for failed firms. Results of tests using this larger sample do not differ significantly from those reported in Table 7. faster recognition of economic gains than economics losses, and with aggressive (instead of conservative) accounting. ${ }^{17}$ These aggressive (instead of conservative) earnings may be the result of: (1) managers in failed firms using accruals to increase earnings (pure accounting manipulation, release of negative accruals, decrease of cost of goods sold), which decreases the predicted negative association between earnings and cash flows; and (2) managers in failed firms relaxing credit policies to increase sales without recognising the proper bad debt provisions (real activities manipulation together with improper accounting policies). The difference in the conservative measures between failed and continuing firms is always significant at 
least at a $1 \%$ level when using the Giner and Rees (2001) approach. The Chow test of fers the same results, except for the good news coefficient in the year prior to failure, where the difference between failed and continuing firms is not significant. ${ }^{18}$

Overall, our results from Tables 6 and 7 show that managers of ex-post failed firms delay the recognition of economic losses and anticipate the recognition of economic gains in an attempt to delay bankruptcy.

\section{Summary and conclusions}

This paper analyses earnings quality in a lar ge sample of UK bankrupt firms. We find that ex-post failed firms engage in earnings manipulation which may begin up to four years prior to failure. We argue that this manipulation responds to managers' attempts at concealing poor performance.

We show that managers use two dif ferent tools to achieve this objective: purely accounting (accruals) manipulation and real activities manipulation.

Our study adds to the literature on the quality of earnings reported by ex-post failed firms in several ways: (1) we analyse two dif ferent aspects of earnings manipulation: accounting manipulation and real activity manipulation. We show managers resort to both, but use more aggressive real activities manipulation when their failure probability is high. This is consistent with arguments in prior literature that managers see real activities manipulation as more costly , and use it only when the available accounting discretion has been used up. (2) We also provide evidence on the timing of the manipulation, as we show it starts four years prior to failure, and unravels in the year just before failure; (3) we show that the manipulation is successful in hiding poor performance (firms with low ex-ante failure probability show aggressive accruals management), which highlights the need for better corporate governance provisions and enforcement of accounting standards, and opens the door for further research on failure prediction models that explicitly control for earnings management practices; (4) we demonstrate that ex-post failed firms report less conditionally conservative earnings, which implies increased agency problems; and finally, (5) we use a UK sample, where the insolvency code allows for a wider definition of bankruptcy, with different implications, than in the US (Franks et al., 1996; Bradbury, 2007).

Regarding our finding that failed firms with a low ex-ante failure probability manage earnings

\footnotetext{
${ }^{18}$ These results are robust to the use of working capital discretionary accruals as the dependent variable in the model. This is indicative of the use of aggressive accounting (pure accounting manipulation).
}

more aggressively, it is very likely that it is precisely the manipulation of earnings that determines the low probability of failure. This result has important regulatory implications, as it suggests that monitoring suspect firms (those with a lar ger failure probability) is not enough to prevent the manipulation in firms with financial dif ficulties. This result also suggests that bankruptcy prediction models may not properly account for managerial accounting choices. This is a potential implication of our work that generates a research question of interest: whether bankruptcy prediction models could improve by explicitly considering accounting manipulation. Finally, the evidence reported on the manipulation of real activities, although admittedly limited due to data constraints, is also of interest, as it raises the issue of sub-optimal decision-making to conceal poor performance. This may be of relevance to claimants and debtholders, as sub-optimal decision-making may reduce the liquidation value of some of the firm assets prior to liquidation.

With respect to ex-post failed firms reporting less conditionally conservative earnings in the years preceding bankruptcy, this is a consequence of both the manipulation of accounting accruals relative to the current level of sales, and the manipulation of real activities to increase current sales. We demonstrate that managers of ex-post bankrupt firms attempt to delay bankruptcy by recognising economic gains earlier and delaying the recognition of economic losses. Given that prior studies show that better governed firms present more conditionally conservative accounting numbers, our results may suggest that failed firms have weaker governance structures that open the door for the manipulation of real activities and to increases in operational risk. However, this is an issue that requires further research to obtain direct evidence. The absence of conditionally conservative accounting practices worsens contracting efficiency, increasing agency costs that af fect both debt-holders (as managers avoid breaking debt covenants), and shareholders (expropriated by managers through compensation contracts that would not have rewarded additional bonuses to managers given the actual performance).

The evidence provided in the present study can be, consequently, useful for regulators, to develop and implement corporate governance provisions to prevent managers' opportunistic behaviour; for auditors, to understand better how managers exercise the discretion inherent in accounting standards to mask poor performance in financially troubled firms; and to other parties (such as analysts, creditors and researchers) who use accounting numbers to assess failure probability, default risk and the liquidation value of the firm. 


\section{References}

ASB. (1999). Statement of Principles for financial r eporting. Accounting Standards Board. ASB Publications. Central Milton Keynes.

Ahmed, A., and Duellman, S. (2007). 'Evidence on the role of accounting conservatism in corporate governance'. Journal of Accounting and Economics, 43: 411-437. Al-Attar, A., Hussain, S., and Zuo, L.Y . (2008). 'Earnings quality, bankruptcy risk and future cash flows', Accounting and Business Research, 38(1): 5-20.

Altman, E. (1968). 'Financial ratios, discriminant analysis, and the prediction of corporate bankruptcy'. Journal of Finance, 23(4): 589-609.

Ball, R., Kothari, S.P . and Robin, A. (2000). 'The ef fect of international institutional factors on properties of accounting earnings'. Journal of Accounting and Economics, 29: 1-51.

Ball, R., Robin, A. and Sadka, G. (2008). 'Is financial reporting shaped by equity markets or by debt markets? An international study of timeliness and conservatism', Review of Accounting Studies, 13(2-3): 168-205.

Ball, R. and Shivakumar L. (2005). 'Earnings quality in UK private firms: comparative loss recognition timeliness'. Journal of Accounting and Economics , 39(1): 83-128.

Barker, R., and Imam, S. (2008), 'Analysts' perceptions of 'earnings quality', Accounting and Business Resear ch, 38(4): 313-329.

Barton, J. and Simko P. J. (2002). 'The balance sheet as an earnings management constraint'. The Accounting Review, 77(4): 1-27.

Bartov, E. (1993). 'The timing of asset sales and earnings manipulation'. The Accounting Review, 68(4): 840-855.

Basu, S. (1997). 'The conservatism principle and the asymmetric timeliness of earnings'. Journal of Accounting and Economics, 24(1): 3-37.

Beaver, W.H. (1966). 'Financial ratios as predictors of failure'. Journal of Accounting Research, 5 (Supplement): 71-111.

Beaver, W.H. and Ryan, S.G. (2005). 'Conditional and unconditional conservatism: concepts and modeling', Review of Accounting Studies, 10: 269-309.

Becker, C., DeFond M., Jiambalvo J. and Subramanyam K. (1998). 'The ef fect of audit quality on earnings management'. Contemporary Accounting Research, 15(1): 1-24. Beekes, W., Pope, P.F. and Young, S. (2004). 'The link between earnings timeliness, earnings conservatism and board composition: evidence from the UK'. Corporate Governance: An International Review, 12(1): 47-51.

Bradbury, M. (2007). 'Discussion of Charitou, Lambertides and Trigeorgis'. Abacus, 43(3): 297-302. Brooks, L. and Buckmaster D. (1976). 'Further evidence of the time series properties of accounting income'. Journal of Finance, 32: 1359-1373.

Bushee, B. J. (1998). 'The influence of institutional investors on myopic R\&D investment behavior Accounting Review, 73(3): 305-333.

Butler, M., Leone, A. J. and Willenborg M. (2004). 'An empirical analysis of auditor reporting and its association with abnormal accruals'. Journal of Accounting and Economics, 37(2): 139-165.

Charitou, A., Lambertides, N. and Trigeorgis, L. (2007a). 'Managerial discretion in distressed firms'. British Accounting Review, 39: 323-346.

Charitou, A., Lambertides, N. and Trigeorgis, L. (2007b). 'Earnings behaviour of financially distressed firms: the role of institutional ownership'. Abacus, 43(3): 271-296. Charitou, A., Neophytou E. and Charalambous C. (2004).
'Predicting corporate failure: empirical evidence for the UK.' European Accounting Review, 13(3): 465-497.

Chung, R., Firth M., and Kim, J.-B. (2003). 'Auditor conservatism and reported earnings'. Accounting and Business Research, 33(1): 19-32.

Cohen, D.A., Dey, A., and Lys, T.Z. (2008). 'Real and accrual based earnings management in the pre and post Sarbanes-Oxley periods'. Accounting Review , 83(3): 757-787.

DeAngelo, H., DeAngelo L. and Skinner ， D. J. (1994). 'Accounting choice in troubled companies'. Journal of Accounting and Economics, 17(1-2): 113-143.

Dechow, P. M. (1994). 'Accounting earnings and cash flows as measures of firm performance: the role of accounting accruals'. Journal of Accounting and Economics, 18(1): 3-42.

Dechow, P. M., Kothari S. P. and Watts R. L. (1998). 'The relation between earnings and cash flows'. Journal of Accounting and Economics, 25(2): 133-168.

Dechow, P. M., Sloan R. G. and Sweeney A. P. (1995). 'Detecting earnings management'. Accounting Review, 70(2): 193-225.

DeFond, M. L. and Jiambalvo J. (1994). 'Debt covenant violation and manipulation of accruals'. Journal of Accounting and Economics, 17(1-2): 145-176.

Demirag, I. S. (1995). 'Assessing short-term perceptions of group finance directors of UK companies'. British Accounting Review, 27(4): 247-281.

Dietrich, J.R., Muller , K.A. and Riedl, E.J. (2007). 'Asymmetric timeliness tests of accounting conservatism'. Review of Accounting Studies, 12: 95-124.

Elgers, P.T. and Lo, M.H. (1994). 'Reduction in analysts' annual earnings forecasts errors using information in prior earnings and security returns'. Journal of Accounting Research, 32: 290-303.

Ezzamel, M. and Mar Molinero, C. (1987). 'On the distributional properties of financial ratios', Journal of Business Finance and Accounting, 14(4): 463-481.

FASB. (1980). Statement of Financial Accounting Concepts No. 2, Qualitative Characteristics of Accounting Information. Financial Accounting Standards Board. Norwalk, Connecticut, CT.

Franks, R.J., Nybor g, K.G. and Torous, W.N. (1996). 'A comparison of US, UK and German insolvency codes', Financial Management, 25(3): 86-101.

García Lara, J.M., García Osma, B. and Mora, A. (2005). 'The effect of earnings management on the asymmetric timeliness of earnings'. Journal of Business, Finance and Accounting, 32: 691-726.

García Lara, J.M., García Osma, B. and Penalva, F. (2007). 'Board of directors' characteristics and conditional accounting conservatism: Spanish Evidence'. European Accounting Review, 16: 727-755.

García Lara, J.M., García Osma, B. and Penalva, F. (2009). 'Accounting conservatism and corporate governance'. Review of Accounting Studies, 14(1): 161-201.

García Osma, B. and Young, S. (2008). 'R\&D expenditures and earnings tar gets'. European Accounting Review. forthcoming.

Gilbert, L.R., Menon, K. and Schwartz, K.B. (1990).

'Predicting Bankruptcy for Firms in Financial Distress', Journal of Business Finance and Accounting, 17(1): 161-171.

Giner, B. and W. Rees. (2001). 'On the asymmetric recognition of good and bad news in France, Germany and the United Kingdom'. Journal of Business, Finance and Accounting, 28: 1285-1331.

Graham, J. R., Harvey, C. R. and Rajgopal, S. (2005). 'The economic implications of corporate financial reporting'. 
Journal of Accounting and Economics, 40(1-3): 3-73. Grinyer, J., Russell, A. and Collison, D. (1998). 'Evidence of managerial short-termism in the UK'. British Journal of Management, 9(1): 13-22.

Guay, W., Kothari, S. and Watts, R. (1996). 'Amarket-based evaluation of discretionary accrual models'. Journal of Accounting Research, 34 (Supplement): 83-115.

Healy, P. M. and Palepu, K. G. (1993). 'The effect of firms' financial disclosure strategies on stock prices'. Accounting Horizons, 7(1): 1-11.

IASC. (1989). Framework for the Pr eparation and Presentation of Financial Statements . International Accounting Standards Committee. London. (adopted from 2001 by the International Accounting Standards Board.).

Insolvency Act (1986). UK insolvency legislation (available at www.insolvency.gov.uk)

Jones, F. L. (1987). 'Current techniques in bankruptcy prediction'. Journal of Accounting Literature, 6: 131-164.

Jones, J. J. (1991). 'Earnings management during import relief investigations'. Journal of Accounting Resear ch, 29(2): 193-228.

Kasznik, R. (1999) 'On the association between voluntary disclosure and earnings management', Journal of Accounting Research, 37(1), 57-81.

LaFond, R., and Watts, R. (2008). 'The information role of conservatism'. The Accounting Review, 83: 443-478.

Mensah, Y. (1984). 'An examination of the stationarity of multivariate bankruptcy prediction models: a methodological study', Journal of Accounting Research, 22(1): 380-395.

Neophytou, E. and Mar Molinero C. (2004). 'Predicting corporate failure in the UK: A multidimensional scaling approach'. Journal of Business Finance and Accounting, 31(5/6): 677-710.

Ohlson, J. A. (1980). 'Financial ratios and the probabilistic prediction of bankruptcy'. Journal of Accounting Research, 19(1): 109-131.

Peasnell, K. V., Pope P. F. and Young S. (2000). 'Accrual management to meet earnings tar gets: UK evidence pre- and post-Cadbury'. British Accounting Review, 32(4): 415-445.

Peltier-Rivest, D. (1999). 'The determinants of accounting choices in troubled companies'. Quarterly Journal of
Business and Economics, 38(4): 28-44.

Qiang, X. (2007). 'The ef fects of contracting, litigation, regulation, and tax costs on conditional and unconditional conservatism: cross-sectional evidence at the firm level', Accounting Review, 82: 759-797.

Richardson, F. M. and Davidson, L. F . (1983). 'An exploration into bankruptcy discriminant model sensitivity', Journal of Business Finance and Accounting, 10(2): 195-207.

Richardson, F. M. and Davidson, L. F . (1984). 'On linear discrimination with accounting ratios', Journal of Business Finance and Accounting, 11(4): 511-525.

Rosner, R. L. (2003). 'Earnings manipulation in failing firms'. Contemporary Accounting Research, 20(2): 361-408.

Roychowdhury, S. (2006). 'Management of earnings through the manipulation of real activities that affect cash flow from operations'. Journal of Accounting and Economics, 42(3): 335-370.

Saleh N. M. and Ahmed, K. (2005). 'Earnings management of distressed firms during debt renegotiation'. Accounting and Business Research, 35(1): 69-86.

Schipper, K. (1989). 'Commentary on earnings management.' Accounting Horizons, 3(4): 91-102.

Smith, M., Kestel, J. and Robinson, P . (2001). 'Economic recession, corporate distress and income increasing accounting policy choice'. Accounting Forum , 25(4): $335-352$.

Subramanyam, K. (1996). 'The pricing of discretionary accruals'. Journal of Accounting and Economics , 22: 249-281.

Sweeney, A. P . (1994). 'Debt-covenant violations and managers' accounting responses'. Journal of Accounting and Economics, 17(3): 281-308.

Watts, R. L. and Zimmerman J. L. (1986). Positive accounting theory. Prentice-Hall, Inc.: Upper Saddle River, New Jersey, NJ.

White, H. (1980). 'A heterokedasticity-consistent covariance matrix estimator and a direct test for heterokedasticity'. Econometrica, 48(4): 817-838.

Young, S. (1999). 'Systematic measurement error in the estimation of discretionary accruals: An evaluation of alternative modeling procedures'. Journal of Business Finance and Accounting, 26(7-8): 833-862. 